\title{
SHARED UNDERSTANDING ON THE CONCEPT OF ENTREPRENEURSHIP EDUCATION BY TEACHERS AND BUSINESSMEN / THE CONCEPT OF ENTREPRENEURSHIP EDUCATION IN LITHUANIAN SCHOOLS SHARED BY TEACHERS AND BUSINESSMEN
}

\author{
Gintautė Žibẻnienė \\ Rita Virbalienė \\ Mykolas Romeris university
}

\begin{abstract}
The article highlights the importance of entrepreneurship education in a modern day educational institution. Strategic documents of the EU invite the educational institutions to cooperate more actively with the business world in order to have the best quality entrepreneurship education. So the main aim of the research is to determine the concept of entrepreneurship shared by teachers and businessmen. Firstly, the concept of entrepreneurship and its development is reviewed, taking into account the legislations and scientist observations. The second part of the article presents the similarities and differences on the concept of entrepreneurship from the point of view of teachers and businessmen. These differences can suggest what relevant aspects, indicated by the representatives of the business world, could be included into the process of organization of the entrepreneurship education and to improve.
\end{abstract}

Keywords: entrepreneurship, entrepreneurship education, teachers, businessmen.

\section{Introduction}

The topic of entrepreneurship and its educational process is discussed in the EU documents and announcements (Commission of the European Communities. Implementing the Community Lisbon Programme: Fostering entrepreneurial mindsets through education and learning, 2006; Entrepreneurship in Vocational Education and Training, 2009; Entrepreneurship education policies, 2011; Entrepreneurship Education: Enabling Teachers as a Critical Success Factor, 2011; Entrepreneurship Education at School in Europe, 2012; Entrepreneurship in Education and Training - from compulsory school to higher education 20092014). The analysis of these sources suggests the importance of entrepreneurial skills, it is also proposed to strengthen entrepreneurship education on all the educational levels, and people are invited to share best practice. The documents also mention the need to raise the qualification of entrepreneurship teaching educators. A more active interest in entrepreneurship started in 2005, when entrepreneurship was listed among the eight competences of lifelong learning (Proposal for a Recommendation of the European Parliament and of the Council on key competences for lifelong learning, 2005). However, it can not be said that there were no discussions about entrepreneurship until then. V. Stokaite (2012) specifies, that the sphere of entrepreneurship attracted the attention even earlier, and indicates the early stage: starting from nineties and lasting until 2005, when the European Union (hereinafter the EU) started promoting general 
initiatives of entrepreneurship education and since 2005 the investigation began, when certain means of entrepreneurship promotion were determined. S. Wennekers and R. Thurik (1999) have a similar opinion: having extensively examined the economic literature, they call 1960-1970 the preparatory phase and this directs our attention to two related phenomena of the 1980s and 1990s: the resurgence of small business and the revival of entrepreneurship.

Lithuanian and foreign researchers have examined various aspects of entrepreneurship, the concept itself, and the qualities and abilities of an enterprising person (Arasti, Falavarjani, 2012; Davies, Gibb 1991; Dudaite, Žibènienè, 2012; Gîmbuţa, 2010; Higgins, Elliott, 2011; Hytti, O'Gorman, 2004; Fayolle, Kyro, 2008; Kozlinska, 2011; Lans T. et al., 2008; Mwasalwiba, 2010; Raposo, do Paco, 2011; Turner, 2005; Timmons, Spinelli, 2008; Sánchez C. J., 2011; Strunga, Martin, 2012; Vázquez-Burgete et al., 2012, etc.). D. Bornstein (2004) observes that a solid definition of entrepreneurship might never be drawn, but emphasizes the need to raise discussions about it. The scholars have also analyzed the realization of entrepreneurial abilities under conditions of targeted education (Gevorgianienè, Galkienè, Grincevičienè, 2008), the promotion of entrepreneurship in higher education, based on the analysis of the EU documents (Stokaite, 2012), the teachers' attitude towards entrepreneurship education (Zaleskienè, Žadeikaite, 2008) and the means of students' entrepreneurial improvement (Župerka, 2009).

The experts on entrepreneurship indicate, that entrepreneurship education is developed differently in various European countries, there is a noticeable encouragement to pay more attention to entrepreneurship and to raise more discussions in order to determine a unified concept of entrepreneurship and entrepreneurship education, to analyze the experiences of others and share the experience on the issues of entrepreneurship education (Entrepreneurship education policies, 2011; Entrepreneurship in Vocational Education and Training, 2009; Entrepreneurship Education at School in Europe, 2012; Towards Greater Cooperation and Coherence in Entrepreneurship Education, 2010). It is highlighted, that entrepreneurship, creativity and innovativeness should be developed on all the levels of the educational system. Since 2009, the European Commission has been preparing and initiating reports on the issues of business development: in 2009, a report was prepared on the matters of entrepreneurship education, in 2010, a short review on the state of entrepreneurship in European countries was prepared, which also was examining the issue of whether the strategy of entrepreneurship education exists, in 2011 a review of the basic problems related to entrepreneurship education and the activity of teachers were presented and in 2012, entrepreneurship education in European schools was presented (Entrepreneurship in Vocational Education and Training, 2009; Towards Greater Cooperation and Coherence in Entrepreneurship Education, 2010; Entrepreneurship Education: Enabling Teachers as a Critical Success Factor, 2011; Entrepreneurship Education at School in Europe, 2012). The 
report of 2012 (Entrepreneurship Education at School in Europe, 2012) suggests that the educational institutions and the business world should collaborate more efficiently, and organize discussions and events inviting to collaborate, by naming the benefits of such collaboration. There are many ways for businessmen to support entrepreneurial teaching and learning: by being experts, supporters, mentors or critical friends (Entrepreneurship Education: A Guide for Educators, 2013).

So, when the skills important to a modern day person are discussed in the European Union as well as the rest of the world, entrepreneurship is mentioned as well, and the result of it, is research on such topics as entrepreneurship and entrepreneurship education. However, there is no unified concept of entrepreneurship and entrepreneurship education; teachers and businessmen in practical education forums also seem unable to agree upon the notion of entrepreneurship and entrepreneurship education, and its development. Sometimes the representatives of the business world express their concerns in the press, during various events and in scientific conferences, that the entrepreneurial skills of a young person can not be properly developed, because teachers do not have entrepreneurial skills themselves, so they are unable to pass this concept to their students properly, or the concept differs from reality as a teacher does not have practical experience. It could be said, that the concept of entrepreneurship and entrepreneurship education was not thoroughly examined and consensus was not reached. The aspect which has not been extensively examined until now is the concept of entrepreneurship education, shared by secondary school entrepreneurship teachers and businessmen. It is important to examine the concept of entrepreneurship, shared by people working in this sphere - the teachers, because these people are direct formal educators of entrepreneurship and it is very likely, that their understanding of entrepreneurship and entrepreneurship education is closely related to the results they want to see in their students. Such understanding is also very important, because there is a need of collaboration between teachers and businessmen in order to develop the entrepreneurial skills of their students, listed in various European documents, and also, these are individuals with the business experience. The question arises whether entrepreneurship teachers and businessmen have a common understanding of what entrepreneurship or entrepreneurship education is? When examining scientific literature, no comparisons on the understanding of this concept were found. Lack of research on this aspect and no clear formulation of the concept of entrepreneurship education result in the scientific research problem. Research object - common understanding of entrepreneurship education shared by teachers and businessmen. Research aim - to determine the concept of entrepreneurship shared by teachers and businessmen.

The method of empirical research and data analysis. Research methods: theoretical analysis of scientific literature and documents, and 
collection of empirical data: a structured interview. During the interview, general methodical instructions of the qualitative research were followed. Interviews were carried out in the workplace of participants, at a convenient time for both: participants and researchers, with regards to the main principles of qualitative interview. The interview was based on voluntary participation; the participants were guaranteed confidentiality. The data obtained from interviews was analyzed, based on the traditional (qualitative) analysis (Krippendorff, 1980, Mayring, 2000): the analysis was carried out systematically, step by step. Multiple text reading was conducted, as well as the justification of the distinguished categories by coding units extracted from the text and their interpretation. Structured interview was applied: all the participants received the same questions. During the interview, the informants were asked what entrepreneurship is, they were asked to describe the education of entrepreneurship, by naming the skills, viewpoint and knowledge that should be developed. 8 experts, 4 business representatives and 4 teachers with the experience in entrepreneurship education ${ }^{3}$ were interviewed (based on the expert sample, defined by B. Bitinas (1998)), by using an expert sample and having reached the information multiplicity. Certain requirements were imposed on the experts, which had to be fulfilled: businessmen - business people with the experience, leaders participating in public discussions on entrepreneurial topics and interested in entrepreneurship. The selected teachers had to fulfil the requirements to experts: to have at least 2 years of work in school experience, working in the sphere of entrepreneurship education; to have a professional qualification, proving the status of a professional teacher, who is teaching entrepreneurship in school (studies to become a specialist in entrepreneurship are offered only in one school in Lithuania - Mykolas Romeris university (Master's program 'Education of entrepreneurship')). The expert method was chosen, as it allows more detailed examination of the analyzed object (Bitinas, 1998). The research was conducted on December, 2013 - January, 2014, in Lithuania.

\section{The concept of entrepreneurship and entrepreneurship education: theoretical aspects}

When analyzing the data and the reports on the situation of entrepreneurship, prepared by joint expert groups, mentored by the European Commission, the encouragement to take care of the strategic organization of entrepreneurship education is visible. In the European countries, some positive changes on the issues of entrepreneurship education are noticed. In 2010, eight countries had entrepreneurship planned or integrated into the curriculum (Towards Greater Cooperation and Coherence in Entrepreneurship Education, 2010). According to

\footnotetext{
${ }^{3}$ In Lithuania, entrepreneurship teachers - individuals organizing the process of education, in accordance with the education program 'Economics and entrepreneurship' of basic and/or secondary education.
} 
the data of 2012, basic education schools in the following European countries have included entrepreneurship into their curriculums ${ }^{4}$ (Entrepreneurship Education at School in Europe, 2012). More and more attention is paid to entrepreneurship education in the European countries: it is becoming one of the strategic objectives of the educational system. When analyzing the EU documents and reports initiated by the European Commission, it is clear, that in the European countries, the attention paid to entrepreneurship as a strategic goal of the educational system is gradually increasing, the number of countries where entrepreneurship is included into the national program is increasing as well, but for the countries which have a goal of achieving good results it is important to improve the following aspects: content and process of entrepreneurship education, organization of entrepreneurship education on various levels, preparation of teachers teaching entrepreneurship, and improvement of their qualification, collaboration with the businessmen (Žibènienè, 2012).

The concept of entrepreneurship. So, it can be noticed, that there is a unanimous agreement, of how important it is to develop the entrepreneurship, encouraging them to become businessmen. However, is the concept of entrepreneurship and entrepreneurship education understood unanimously? K.Oganisjana and T.Koke (2012) have indicated nine constituent parts of entrepreneurship: personality, abilities, learning, motivation, emotions, needs, cognition, behaviour, and have stressed that entrepreneurship is not a mechanical combination of separate parts, but more of a dynamic system, where elements are interrelated and based on composite functions. P.Kaufmann and R.P.Dant (1998) generalize the concept by distinguishing between three main aspects, when it is related to: 1) the qualities characterizing a certain individual: creativity, ability to solve problems, ability to make decisions, critical thinking, leadership, motivation, initiative, etc.; 2) foundation of new companies, introduction of new products; 3) entrepreneurial activities. According to C.Turner (2005), entrepreneurship is a volunteer joint work, risk taking, creation, implementation and the ability to raise and successfully implement innovative ideas. Z. Lydeka (2000) highlights the importance of innovative thinking and active and risky activity in all the situations of life. L.Gegieckiene and A.Grikšienè explain entrepreneurship similarly, by distinguishing between two concepts of entrepreneurship: 1) innovative thinking, active and risky actions in all the situations; 2) ability to organize and control your life and business, to make profit by manufacturing goods or providing services (Gegieckienè, Grikšienè, 2009). To summarize, it can be said, that the scientific literature distinguishes between two main approaches to entrepreneurship: 1) personality traits helping to create economic value are accentuated,

\footnotetext{
4 Austria, Czech Republic, Denmark, United Kingdom, Estonia, Romania, Latvia, Poland, Lichtenstein, Lithuania, Luxembourg, Slovakia, Slovenia, Sweden, and it was included into the curriculum of secondary schools as a compulsory subject by the following countries: Austria, Czech Republic, Estonia, United Kingdom, Italy, Poland, Lichtenstein, Lithuania, Luxembourg, Slovakia, Slovenia, Sweden, Hungary
} 
2) suggestions of how to create a social value by employing critical thinking, being creative, receptive to innovations and able to act independently in the knowledge society.

European documents provide a holistic approach to entrepreneurship, because entrepreneurship is described as person's ability to turn ideas into actions, creativity, innovative thinking, readiness to take risk and ability to plan and control the projects. It is also stated, that entrepreneurship is necessary for everyone in their everyday life, work and public, it allows employees to better understand the context of their work and to exploit the opportunities, enables entrepreneurs to start social and commercial activities (Proposal for a Recommendation of the European Parliament and of the Council on key competences for lifelong learning, 2005). In the recommendation 2006/962/EC of the European Parliament and of the Council of 18 December, 2006 on key competences for lifelong learning (2006) the sense of initiative and entrepreneurship is described: 'as the ability to turn ideas into action. It involves creativity, innovation and risk-taking, as well as the ability to plan and manage projects in order to achieve the objectives. An individual is aware of the context of his/her work and is able to seize opportunities that arise. It is the foundation for acquiring more specific skills and knowledge needed by those establishing or contributing to social or commercial activity. This should include awareness of ethical values and promote good governance' (2006; p.1).

Development of entrepreneurship. The document of the Commission of the European Communities notes, that the economic education and development of entrepreneurial skills has a big importance; each citizen needs knowledge of entrepreneurship and entrepreneurial skills, so entrepreneurial skills could be developed as early as when a child is in kindergarten, and they must be taught in school (Implementing the Community Lisbon Programme: Fostering entrepreneurial mindsets through education and learning, 2006). The notion of entrepreneurship education is related to the knowledge and skills, which a student has to acquire. The literature analysis shows that there is no common concept; it is often related to economic environment, business knowledge, ability to work individually and in a team, creativity, ability to make decisions, to evaluate the strong and weak sides, to assess the situation and to take risk. According to L.Minciene (2000), entrepreneurship education is successful, when a certain result is reached, namely the motivation of an individual and responsibility for the development of the basic skills, obtaining a profession, ability to apply the knowledge in practice: searching for a job or setting up a business. Having analyzed a lot of sources of scientific literature on economics, S.Wennekers and R.Thurik (1999) generalize, that the result of entrepreneurship education is: a person who assumes the risk associated with uncertainty; the supplier of financial capital; an innovator; a decision-maker; an industrial leader; a manager or a superintendent; an organizer and coordinator of economic resources; the owner of an enterprise; an employer of production factors; a 
contractor; an arbitrageur; an allocator of resources among alternative uses; a person who realizes a start-up of a new business. As G.Strazdienè and A.Garalis (2005) observe, entrepreneurship education is the development of abilities, necessary to start and develop a business. According to J. L. Vázquez-Burgete et al. (2012), when developing entrepreneurial skills, it is important to gain some entrepreneurial knowledge, abilities and attitudes, which would help to acquire entrepreneurial competences. The knowledge of entrepreneurship includes opportunities for personal, professional and/or business activities, fair trade and social entrepreneurship..., entrepreneurial skills proactive project management, representation and negotiation, autonomous and collaborative work and qualities: initiative, pro-activeness, independence, innovativeness, motivation and determination... C.Turner (2005) stresses a bit different aspects and those are: volunteer collaborative work, risk taking, creation, implementation, ability to raise and successfully implement innovative ideas. So, scientists do not reach consensus, when talking about the constituent parts of the notion of entrepreneurship.

\section{The notion of entrepreneurship education shared by teachers and businessmen}

The main aim of the interviews with businessmen and teachers was to determine the concept of entrepreneurship and entrepreneurship education. The experts participating in the interview firstly had to identify the concept of entrepreneurship. Businessmen (3 out of 4) link the notion of entrepreneurship with the start of the business: '...it's a person's ability to turn the ideas into actions and to create an actual added value to yourself and to the whole community...', ,...these are the personality traits, necessary to start a business and develop it'; '...it is a way of thinking and personal, social, managerial and personal competences, allowing to apply the knowledge in everyday life, i.e. specific skills, providing the opportunity not only to organize the business, but also to take risks for the decisions that were made...'. Only one out of all the businessmen participating in the research did not indicate the direct link between entrepreneurship and the creation of business, and identified it as a person's '... social responsibility ... personal characteristics leading to a purposeful development and the achievement of results, creation of a workplace'. The opinion of teachers split in half, one half thinks that entrepreneurship is an ability to realize the ideas, creativity, innovativeness, willingness to take risk, establish a business and implement new business ideas, and the other half focuses on general skills. In their opinion, entrepreneurship is ' ... an ability to transform the ideas into real projects...', 'ability to manage the finances', '... sociability, creativity, courage to take risks...', '... receptivity to innovations...', '...ability to achieve the objectives...'. Based on the experts' answers it is clear, that even though people were interviewed individually, both: 
businessmen and teachers unanimously agree, that entrepreneurship is a person's ability to turn the ideas into actions, also both groups emphasize the importance of certain abilities, acquired or developed. However, businessmen did not name certain personal qualities, when defining entrepreneurship, while teachers attempted to do that. All of them have mentioned: creativity, innovativeness / receptivity to innovations, setting and achieving the goals or the implementation of an idea. All the businessmen associate entrepreneurship with the creation and implementation of business ideas, and the teachers think differently. Half of them would agree with businessmen, by linking entrepreneurship with creation and implementation of business ideas and the general personal skills, but the other half only mentions the general skills, and do not emphasize the importance of establishing a business when talking about entrepreneurship. A question arises, why businessmen (even though the experts represent different areas of business) have a similar understanding about entrepreneurship, and teachers (experts, professionals in entrepreneurship education) have a different opinion. There are a few possible answers. Firstly, there is no unified concept of entrepreneurship (Oganisjana, Koke, 2012; Dudaitė, Žibènienė, 2012; Kaufmann, Dant, 1998; Župerka, 2010). D. Bornstein (2004) even notes, that there might never be one. The other reason is a quite abstract description of entrepreneurship and entrepreneurship education in the educational documents in Lithuania. According to the educational documents in Lithuania, i.e. general curricula, Entrepreneurship education in Lithuania is creation of the conditions to deepen the business knowledge and understanding, to develop practical skills in entrepreneurship, so that the students could orient properly and act successfully in an ever changing economic environment, to form the point of view, based on the concept of a modern day economy: the constantly changing economic conditions (Ekonomijos ir verslumo vidurinio ugdymo bendroji programa, 2011; Ekonomijos ir verslumo pagrindinio ugdymo bendroji programa, 2008).

A question arises, whether teachers and businessmen have a similar or a different understanding of the concept. In order to determine the concept of entrepreneurship education, the structure of entrepreneurial competence by J. L. Vázquez-Burgete et al. (2012) was chosen. Also, in the Secondary education curriculum of economics and entrepreneurship (2011) and the Basic education curriculum of economics and entrepreneurship (2008) the content of entrepreneurship education is revealed through the same structural parts: knowledge / understanding, abilities and attitudes. The answers of experts were analyzed by dividing them into categories and subcategories, and in this way, the knowledge, abilities and personality traits relevant to entrepreneurship education were determined (Table 1). Businessmen coded by the letter ' $\mathrm{B}$ ' and a digit and teachers - by a letter ' $\mathrm{T}$ ' and a digit. 


\section{The concept of entrepreneurship education of teachers and business representatives}

\begin{tabular}{|c|c|c|}
\hline Category & Sub-category & Supporting statements \\
\hline \multirow[t]{2}{*}{ Knowledge } & $\begin{array}{l}\text { Knowledge of } \\
\text { business } \\
\text { implementatio } \\
\mathrm{n} \text { and } \\
\text { development, } \\
\text { knowledge of } \\
\text { management } \\
\text { and economics }\end{array}$ & $\begin{array}{l}\text { Management (B1), personnel management (B2); marketing (B1; } \\
\text { B4), the knowledge of market needs (B2), market economy (T1, } \\
\text { T4); business and economics (B1), business development (T1), } \\
\text { economics and principles of macroeconomics and } \\
\text { microeconomics (B3); finances (B1; B2; B3); tax knowledge } \\
\text { (B1); foundation of a company, organization of its work activities } \\
\text { (B2), business organization (T1, T4); economic literacy (B2), } \\
\text { management of personal finances (T1, T2, T3, T3). }\end{array}$ \\
\hline & $\begin{array}{l}\text { Other types of } \\
\text { knowledge, } \\
\text { non-related to } \\
\text { business }\end{array}$ & $\begin{array}{l}\text { Specific knowledge related to the activities in a specific sphere } \\
\text { (B1), legal issues (B1, B4), psychology of communication (B2, } \\
\text { B4), knowledge of how to find information (B1). }\end{array}$ \\
\hline \multirow[t]{4}{*}{ Abilities } & $\begin{array}{l}\text { Creation and } \\
\text { development } \\
\text { of business }\end{array}$ & $\begin{array}{l}\text { Ability to do business (B1); ability to objectively assess the } \\
\text { environment and the necessity of a product / service (B3); ability } \\
\text { to assess the potential risks (B3); ability to apply the knowledge in } \\
\text { economics, management, in everyday life (B3); assuming the risk } \\
\text { for the decisions made (B3), risk management (B4). }\end{array}$ \\
\hline & Managerial & $\begin{array}{l}\text { Managerial (B2); organization of the activities for oneself and } \\
\text { others (B2). }\end{array}$ \\
\hline & $\begin{array}{l}\text { Learning to } \\
\text { learn }\end{array}$ & Being able to learn and improve individually (B2). \\
\hline & General skills & $\begin{array}{l}\text { Trying to reach the goals (B1); critical thinking (B2; B4); problem } \\
\text { solving (B2); communication (B2, T3); assuming responsibility } \\
\text { for the implementation of goals (B1), assuming responsibility in } \\
\text { general sense (B4); making informed decisions (B1, B4, T1, T3); } \\
\text { being able to raise your goals (T1, T2); collecting a team for } \\
\text { mutual activity (T3); working in a team (T2), making decisions } \\
\text { (T2, T4); selling one's ideas (T1). }\end{array}$ \\
\hline \multirow[t]{2}{*}{$\begin{array}{l}\text { Attitudes } \\
\text { and } \\
\text { personal } \\
\text { characteris- } \\
\text { tics }\end{array}$} & $\begin{array}{l}\text { Personal } \\
\text { characteristics }\end{array}$ & $\begin{array}{l}\text { Diligence (B1); creativity (B2, B3, T1, T3, T4); motivation (B1); } \\
\text { initiative (B2); independence (B2, T3); self-confidence (B3); } \\
\text { control (B4); sociability (B3); optimism (T2); exuberance (T1); } \\
\text { self-confidence and perseverance (T4); curiosity (T2); tolerance } \\
\text { (T2); responsibility (T2, T4); ingenuity (T3); motivation (T2); } \\
\text { logical thinking (T4); determination (T3); leadership (T2, T4); } \\
\text { innovativeness (T1). }\end{array}$ \\
\hline & Attitudes & $\begin{array}{l}\text { Raising positive goals to oneself (B1); following the moral and } \\
\text { legal principles (B2); moral values (T2); coordination of personal } \\
\text { and public interests (B2); desire to excel, broad outlook, } \\
\text { worldliness (B3, T1); continuous improvement, pursuit of one's } \\
\text { goals (T2); desire to broaden and deepen the knowledge (T3); } \\
\text { striving for constant improvement, moving forward (T4); } \\
\text { systematic learning (T4). }\end{array}$ \\
\hline
\end{tabular}


When analyzing the concept shared by teachers and businessmen, it was determined, what knowledge is important for developing entrepreneurship, this is the knowledge of creating and developing business, management, economics, and other types of knowledge non-related to business. It became clear, that businessmen link entrepreneurship education to the knowledge of management, personnel management, marketing, economics, finances, economic literacy, and the teachers list the knowledge of business development, business organization and market economy. However, all the teachers found the knowledge of the management of personal finances to be important, while it was not mentioned by a single businessman. Yet, neither of the teachers named knowledge that would be related to a different sphere, than business, and according to the businessmen, specific knowledge related to the spheres of activity, legal issues, psychology of communication and knowledge of where to find the information is important (see Table 1). The question then arises, as to why the teachers only mentioned the knowledge of business development, organization and market economy. It could be assumed, that teachers relate the concept of entrepreneurship education with the content of education documents, regulating the entrepreneurship education and the content of the subject 'Economics and entrepreneurship', on the aspect of the knowledge gained. In the Strategy of economic literacy and entrepreneurship education $(2004 \mathrm{~m}$.) it is noted, that every student has to develop entrepreneurship, have the basic knowledge of market economy and know what personality traits he should possess and how to develop them, so that he could successfully use the possibilities of market economy. In the Secondary education curriculum of economics and entrepreneurship (2011), one out of three tasks is to make the students understand '... the trends and prospects of developing a business and be able to apply the knowledge of economics in real life'.

The category 'abilities' made it clear, that businessmen connect the entrepreneurship education with the abilities of business development and expansion (ability to do business; ability to objectively assess the environment and the need for product / service; ability to assess the potential risks; ability to apply the knowledge in economics, management, in everyday life; assuming the risk for the decisions made, risk management), also with managerial abilities (to organize activities for oneself and others) and abilities of learning to teach (to improve and learn individually) see Table 1 . Both, teachers and businessmen see the concept of entrepreneurship education as related to the acquisition of basic skills. However, the teachers only mentioned the basic skills. Why? Is it because, according to I. Zaleskiene, L. Žadeikaite (2008), 'teachers do not feel ready for the process of entrepreneurship education' (2008, p. 103)? Still the authors of the article tend to think, that teachers only stressed the importance of the basic skills, because they related those skills with the content of public education programs. In the National curriculum of economics and entrepreneurship (for secondary school/ gymnasium) the acquisition of 
knowledge and attitudes is emphasized and the abilities are not clearly related to the concept of entrepreneurship: it is not very clear, which abilities are important to the economic and which to entrepreneurial part of the program. For example, in the Basic education curriculum of economy and entrepreneurship (2008) and Secondary education curriculum of economy and entrepreneurship (2011) 5 main topics are listed: market orientation, management of personal finances, business organisation and development of entrepreneurial skills, participation in the international market and role in the economy and analysis and evaluation of the economic indicators. Based on the chapter 'Business organization and development of entrepreneurship skills', a student of the secondary school has to gain four main abilities 'to be able to explain why a certain type of business is developed in different regions, towns, cities; to be able to evaluate the importance of new technologies; to be able to use the physical capital - tools and equipment - to increase the productivity; to be able to evaluate the meaning of new inventions and innovations during different times in history' (Basic education curriculum of economy and entrepreneurship, 2008, p. 105-106). And in secondary school, 11-12 grade students have to develop the basic ability to 'critically evaluate the environment of business development, tendencies and perspectives of the development, the importance of science and information to business" (Secondary education curriculum of economy and entrepreneurship, 2011, p. 108). Teachers, as well as businessmen, relate entrepreneurship to the ability of making informed decisions and businessmen - with the ability to assume responsibility for the accurate realization of the goals raised. It is related to the concept by R. R. Hébert and A. N. Link of what an entrepreneurial person should be able to do: 'the entrepreneur is someone who specializes in taking responsibility for and making judgmental decisions that affect the location, form, and the use of goods, resources, or institutions' (1989, p. 47).

By uncovering the concept of entrepreneurship education, teachers and businessmen have indicated the personality traits and attitudes which need to be developed. Businessmen, especially teachers, have provided an extensive list of the personality traits of an entrepreneurial person, found in scientific literature, as well as the European documents, indicated as educational. These are the following: diligence, creativity, motivation, initiative, independence, selfconfidence, control, sociability, optimism, exuberance, self-confidence and perseverance, curiosity, tolerance, responsibility, ingenuity, motivation, logical thinking, determination, leadership, innovativeness (see Table 1). Businessmen and teachers highlight the quality of being guided by values and reaching for the goals (setting positive goals to oneself (B1); following the moral and legal principles in their activities (B2); the moral values (T2). All the teachers have mentioned the feature of continuous systematic learning, and not all the businessmen have mentioned that. 


\section{Conclusions}

1. Based on the European documents, entrepreneurship education is one of the top priority tasks; it is important to nurture an individual, which has critical thinking, is receptive to innovation and able to act independently in various spheres and to create the social value.

2. According to the study, both: teachers and businessmen, agree, that the person's ability to turn ideas into actions is very important, also, the importance of acquired or cultivated personal qualities is emphasized unanimously, but there is no unified answer whether entrepreneurship should or should not be linked to business development.

3. Businessmen relate entrepreneurship education to the knowledge of management, staff management, marketing, economy, finances, economic literacy, while teachers indicate the knowledge of business development, business organisation and market economy. All the teachers mentioned the knowledge of the management of personal finances, while neither of the businessmen spoke about it. Both: teachers and businessmen, link the concept of entrepreneurship education with the ability to make informed decisions and businessmen - with the ability to take responsibility for the accurate realization of the aims raised. Businessmen and teachers have a similar concept about what qualities and features need to be developed, but teachers, as professional educators, present them more extensively, by following the theory of holistic education.

4. It was shown, that the concept of entrepreneurship education as understood by teachers, is greatly affected by the national documents, which regulate the entrepreneurship education, because their opinion is related to the content of these documents.

\section{References}

1. Arasti, Z., Falavarjani, K.M. (2012). Imanipour N. A Study of Teaching Methods in Entrepreneurship Education for Graduate Students. Higher Education Studies, 1(2), p. 110.

2. Recommendation 2006/962/EC of the European Parliament and of the Council of 18 December 2006 on key competences for lifelong learning [Official Journal L 394 of 30.12.2006]. Brussels: European Commission.

3. Bitinas, B. (1998). Ugdymo tyrimu metodologija. Vilnius: Jošara.

4. Bornstein, D. (2004). How to Change the World: Social Entrepreneurs and the Power of New Ideas. Oxford: Oxford University Pres.

5. Davies, L.G., Gibb, A.A. (1991). Recent research in entrepreneurship, Gower, London, Proceedings of the 3rd International EIASM Workshop.

6. Dudaite, J., Žibėnienè, G. (2012). The concepts of entrepreneurship and entrepreneurial training of the professors' implementing the study programme of educology of entrepreneurship. Social work, 1 (11), p. 165-176.

7. Entrepreneurship education policies. Investment, Enterprise and Development Commission Multi-year Expert Meeting on Enterprise Development Policies and Capacity-building in Science, Technology and Innovation (STI). Third session Geneva, 
19-21 January 2011.

8. Entrepreneurship Education: Enabling Teachers as a Critical Success Factor. A report on Teacher Education and Training to prepare teachers for the challenge of entrepreneurchip education, 2011.

9. Entrepreneurship Education at School in Europe, 2012. Retrieved from http://eacea.ec.europa.eu/education/eurydice/documents/thematic_reports/135EN.pdf.

10. Entrepreneurship in Vocational Education and Training, 2009. Retrieved from http://ec.europa.eu/enterprise/policies/sme/files/smes/vocational/entr_voca_en.pdf.

11. Entrepreneurship in Education and Training-from school to higher education 2009-2014. Retrieved from

http://planipolis.iiep.unesco.org/upload/Norway/Norway_Action_Plan_Entrepreneurship_ 2009_2014.pdf

12. Entrepreneurship Education: A Guide for Educators. Bruxelles: Enterprise and Industry, June 2013. Retrieved from

http://ec.europa.eu/enterprise/policies/sme/promotingentrepreneurship/files/education/entr edu-manual-fv_en.pdf

13. Ekonomijos ir verslumo vidurinio ugdymo bendroji programa, patvirtinta LR švietimo ir mokslo ministro 2011-02-21 įsakymu Nr. ISAK-V-269.

14. Ekonomijos ir verslumo pagrindinio ugdymo bendroji programa, patvirtinta LR švietimo ir mokslo ministro 2008-08-26 įsakymu Nr. ISAK-2433.

15. Ekonominio raštingumo ir verslumo ugdymo strategija, patvirtinta LR švietimo ir mokslo ministro 2004-06-02 įsakymu Nr. ISAK-835.

16. Implementing the Community Lisbon Programme: Fostering entrepreneurial mindsets through education and learning. Commission of the European Communities. 13.2.2006 $\operatorname{COM}(2006) 33$ final.

17. Gevorgianienè, V.; Galkienè, A.; Grincevičienè, V. (2008). Verslumo gebėjimų raiška kryptingo ugdymo sąlygomis. Pedagogika, (89), p. 90-98.

18. Gîmbuţa A. (2010). Entrepreneurial competences from syntegrative perspective. Journal Plus Education, 2, p. 262 - 272.

19. Hébert, R. F. and A. N. Link (1989), 'In Search of the Meaning of Entrepreneurship', Small Business Economics 1, p. $39-49$.

20. Hytti U., O'Gorman, C. (2004). What is "enterprise education"? Education + Training, 1 (46), p. $11-23$.

21. Fayolle, A., Kyro, P. (2008). The Dynamic between entrepreneurship, environment and education. JK: Edvard Elgar Pubishing Limited.

22. Kaufmann, P., J., Dant, R. P. (1998). Franchising and the domain of entrepreneurship reseach. Journal of Business venturing, (14), p. 5-16.

23. Proposal for a Recommendation of the European Parliament and of the Council on key competences for lifelong learning, 2005. Brussels: European Commission, KOM (2005) 548.

24. Kozlinska I. (2011). Contemprorary Approaches to Entrepreneurship Education. Journal of Business Management, 4, p. 205 - 220.

25. Krippendorff, K. (1980). Content Analysis: An Introduction to its Methodology. Beverly Hills, California: Sage Publications.

26. Lans T. et al. (2008). Entrepreneurship Education and Training in a Small Business Context: Insights from the Competence-Based Approach. Journal of Enterprising Culture, 4 (16), p. $363-383$.

27. Mayring, P. (2000). Qualitative Content Analysis. Forum: Qualitative Social Research, 1(2).

28. Mincienè, L. (2000). Verslumo pradmenys. Vilnius. 
29. Mwasalwiba,E. S., 2010. Entrepreneurship education: a review of its objectives, teaching methods, and impact indicators. Education and Training, 1(52), p. $20-47$.

30. Oganisjana, K., Koke, T. (2012). Does competence-Oriented Higher Education Lead to Students' Competitiveness? Engineering Economics, No. 1(23), p. 77-82.

31. Proposal for a Recommendation of the European Parliament and of the Council on key competences for lifelong learning. COM/2005/0548, final - COD 2005/)

32. Raposo, M., do Paco, A. (2011). Entrepreneurship education: relationship between education and entrepreneurial activity. Psicothema, 3(23), p. 453-457.

33. Sánchez, C. J. (2011). University training for entrepreneurial competencies: Its impact on intention of venture creation. International Entrepreneurship and Management Journal, 2(7), p. $239-254$.

34. Stokaite, V. (2012). Promoting entrepreneurship in higher education: analysis of European union documents and Lithuanian case study. Social technologies, 2 (1), p. 139-155.

35. Strunga, A., Martin, C. (2012). Mentoring and eMentoring in entrepreneurial education: CReBUS perspective. Journal of Educational Sciences, No. 1(14), p. 54 - 59.

36. Vázquez-Burgete, J.L. et al. (2012). Entrepreneurship Education in Humanities and Social Sciences: are Students Qualified to Start a Business? Business, 1(13), p. 27 - 35.

37. Timmons, J., Spinelli, S. (2008). New venture creation: Entrepreneurship for the 21st Century.. London: McGraw Hill.

38. Towards Greater Cooperation and Coherence in Entrepreneurship Education, 2010. Report and Evaluation of the Pilot Action High Level Reflection Panels on Enrepreneurship Education initiated by DG Enterprise and Industry and DG Education and Culture.

39. Turner, C. (2005). Veskite i sèkmę. Kaip sukurti verslias organizacijas. BMI: Baltos lankos.

40. Zaleskienè, I.; Žadeikaitè, L. (2008). Mokytojų požiūris ị verslumo ugdymo prielaidas. Pedagogika, 89, p. 99-106.

41. Žibènienè, G. (2012). The entrepreneurial teacher continuing training: challenges and problems in Europe. Social work, 2 (11), p. 379-390.

42. Župerka, A. Moksleivių verslumo ugdymo tobulinimo kryptys Lietuvoje. Imoniu ekonomika ir vadyba. 2009: 299-311.

43. Župerka A. (2010). Studentu verslumo ugdymo plètra Lietuvoje [daktaro disertacija]. VDU.

44. Wennekers, S. and R. Thurik (1999). Linking entrepreneurship and economic growth, Small Business Economics, 13(1), p. 27-55.

dr., assoc. prof.

Gintautè Žibènienè

lecturer

Rita Virbalienè
Mykolas Romeris University, Institute of Educational Sciences and Social Work, Ateities g. 20, LT-08303, Vilnius E-mail: zibeniene@mruni.eu

Mykolas Romeris University, Institute of Educational Sciences and Social Work, Ateities g. 20, LT-08303, Vilnius E-mail: rivirb@mruni.eu 